\title{
Kemampuan Reagen Curcumax Mendeteksi Boraks dalam Bakso yang Direbus
}

\section{Capability of Curcumax reagent to detect borax in boiled meatballs}

\author{
Erna Dwi Astuti' ${ }^{1}$ Widagdo Sri Nugroho ${ }^{2}$ \\ ${ }^{1}$ Fakultas Kedokteran Hewan, Universitas Gadjah Mada \\ ${ }^{2}$ Laboratorium Kesehatan Masyarakat Veteriner, Fakultas Kedokteran Hewan, \\ Universitas Gadjah Mada, J1 Fauna no 2, Karangmalang, Yogyakarta \\ Telepon/Fax: 0274-560866. Email: weesnugroho@ugm.ac.id
}

\begin{abstract}
Borax is a harmful compound to human health but sometimes was used illegally as preservative in meatball. Curcumax reagent is a compound which developed from the previous borax detector base on tumeric extract. This reagen was developed as an easy kit to apply in the field. This study aims were to determine accuracy of sight obesrvation and spectrophotometer to detected borax in boiled meatballs which tested by Curcumax and to determine the effect of boiling on the borax presence in the meatballs. This study was using meatballs group as a control and another meatballs group preserve with borax $0.5 \%$. Each treatment group was boiled in $0,5,10$, and 15 minutes and each treatment unit had three replications which consist five meatballs each of them. Borax detection was done by mixing $1 \mathrm{ml}$ Curcumax reagent into $1 \mathrm{ml}$ meatball extract. Qualitative examination of borax presence in the meatballs was known based on the color changing of tested meatball's extract from yellow became orange (direct sight with eyes). The Quantitaive analysis was done by measured using spectrophotometer base on wave-length $(\lambda)$ at $570 \mathrm{~nm}$. Data was analyzed with ANOVA and continued by Least Significant Difference (LSD) analysis. Borax detection using curcumax based on sight sense against color change giving an inconsistence result. Meanwhile quantitative measurement by spectrophotometer more accurate than one. Curcumax had been detected borax in meatball which boiled for 15 minutes.
\end{abstract}

Keywords : borax, meatballs, Curcumax, spectrophotometry

\begin{abstract}
Abstrak
Boraks merupakan zat kimia yang berbahaya bagi kesehatan masyarakat namun seringkali digunakan dalam bakso. Pengembangan alat deteksi boraks yang praktis sangat diperlukan di lapangan. Reagen Curcumax adalah hasil pengembangan alat deteksi boraks yang berbahan dasar ekstrak kunyit. Penelitian ini bertujuan mengetahui ketelitian pengamatan indra penglihatan dan spektrofotometer dalam mendeteksi boraks dalam bakso yang direbus yang diuji menggunakan reagen Curcumax dan mengetahui pengaruh perebusan terhadap keberadaan boraks dalam bakso. Penelitian ini menggunakan kelompok bakso kontrol dan kelompok bakso boraks $0,5 \%$ dengan perlakuan perebusan selama $0,5,10$ dan 15 menit. Setiap unit perlakuan dilakukan ulangan sebanyak 3 kali yang masingmasing tediri dari 5 butir bakso. Pemeriksaan kandungan boraks dilakukan dengan cara $1 \mathrm{ml}$ ekstrak bakso diuji dengan $1 \mathrm{ml}$ reagen Curcumax. Penilaian keberadaan boraks secara kualitatif didasarkan pada perubahan warna ekstrak bakso yang berubah dari kuning menjadi oranye. Pemeriksaan kuantitaif dilakukan dengan cara mengukur intensitas warna ekstrak bakso yang telah ditetesi Curcumax dengan spektrofotometer pada panjang gelombang 570 $\mathrm{nm}$. Data dianalisis dengan ANOVA dan dilanjutkan dengan analisis Least Significant Difference(LSD). Penilaian kulitatif boraks berdasarkan pengamatan indra penglihatan memberikan hasil yang tidak konsisten sementara penilaian berdasarkan spektrofotometer lebih akurat. Perebusan mengurangi kandungan boraks dalam bakso. Reagen Curcumax mampu mendeteksi boraks dalam bakso yang direbus hingga 15 menit.
\end{abstract}

Kata kunci : boraks, bakso, Curcumax, spektrofotometer 


\section{Pendahuluan}

Boraks merupakan zat kimia yang tidak termasuk sebagai bahan tambahan pangan namun beberapa kali digunakan dalam pembuatan bakso. Penambahan boraks dalam bakso bertujuan agar bakso menjadi kenyal dan awet. Boraks adalah zat yang digunakan untuk anti jamur, bahan pengawet kayu, dan bahan antiseptik pada kosmetik. Senyawa tersebut juga digunakan sebagai insektisida untuk membunuh semut, kecoa, dan lalat (Sugiyatmi, 2006). Asam borak juga digunakan dalam pemeliharan ayam potong terutama untuk pengendalian jamur dan kutu pada litter/alas kandang. Sander et al. (1991) menemukan bahwa dosis asam borak sebesar $2,95 \pm 0,35 \mathrm{~g} / \mathrm{kg}$ BB pada ayam umur satu hari (day old chick/DOC) mampu menimbulkan kematian namun hanya menimbulkan toksisitas ringan pada ayam yang lebih dewasa. Penelitian tersebut juga dibuktikan bahwa dengan pemberian asam borak dengan dosis $500 \mathrm{ppm}$ atau $1250 \mathrm{ppm}$ dalam pakan selama 3 minggu tidak cukup meningkatkan residu asam borak di dalam jaringan ayam.

Kontaminasi boraks dalam jumlah yang besar di dalam makanan menyebabkan keracunan pada manusia dengan gejala klinis yaitu batuk, iritasi mata, muntah, kesulitan bernafas, toksisitas pada sel, dan terkadang kematian (See et al., 2010). Di Kuala Lumpur Malaysia, Yiu et al. (2008) mendapatkan fakta baha di dalam bakso ikan ditemukan kandungan asam borak dengan konsentrasi yang bervariasi dari $0,86 \mu \mathrm{g} / \mathrm{g}$ sampai dengan $1,58 \mu \mathrm{g} / \mathrm{g}$. Litovitz et al. (2008) yang disitasi oleh See et al. (2010) menyebutkan bahwa bayi yang baru lahir dapat meninggal apabila mengonsumsi asam borat dengan dosis 3-6 g sementara untuk orang dewasa dengan dosis 15-20 g. Fakta tersebut menarik dihubungkan dengan bakso yang dijual di Indonesia yang juga sering diberitakan mengandung borak. Keberadaan bakso yang dimasukkan dalam panci panas (direbus) beberapa saat sebelum disajikan menarik untuk diketahui dampaknya terhadap konsentrasi boraks di dalamnya.

Curcumax adalah nama reagen yang diformulasikan Arifin et al. (20012) terdiri dari campuran asam klorida pekat, polyvinyl alcohol (PVA), kunyit, dan akuades. Reagen Curcumax mampu mendeteksi boraks dalam bakso hingga konsentrasi $0,5 \%$. Reagen ini praktis dan mudah digunakan di lapangan (Arifin et al., 2012).

Penelitian ini bertujuan untuk mengetahui kemampuan reagen Curcumax mendeteksi boraks berdasarkan pengamatan indera penglihatan dan spektrofotometer, serta mengetahui pengaruh pemanasan terhadap keberadaan boraks di dalam bakso.

\section{Materi dan Metode}

Bakso dibuat menjadi 2 kelompok, yaitu kelompok kontrol (tanpa boraks) dan kelompok yang mengandung boraks $0,5 \%$. Masing-masing kelompok diberi perlakuan perebusan ulang dengan waktu 0,5 , 10, dan 15 menit. Setiap perlakuan waktu perebusan pada bakso boraks dibuat 3 ulangan dan setiap ulangan terdiri 5 butir bakso. Pengujian keberadaan borak dilakukan dengan dua metode. Metode pertama secara kualitatif yaitu pengamatan langsung dengan indra penglihatan dan metode kedua dengan pengukuran absorbansi berdasarkan panjang gelombang menggunakan spektrofotometer.

Metode pengujian boraks dalam bakso. Setiap bakso sampel ditimbang 5 gram diekstraksi dengan 
$10 \mathrm{ml}$ etanol analisis, selanjutnya $1 \mathrm{ml}$ ekstrak sampel dimasukkan ke dalam tabung reaksi dan ditambah dengan $1 \mathrm{ml}$ reagen Curcumax. Campuran ekstrak sampel dengan reagen Curcumax divortex hingga homogen kemudian dilakukan penilaian. Ekstrak sampel yang mengandung boraks akan berubah warna menjadi oranye. Penilaian metode pertama dilakukan dengan mengamati berdasarkan indra penglihatan terhadap perubahan warna ektraks sampel. Data yang diperolah berupa jumlah sampel bakso yang mengalami perubahan warna menjadi oranye (mengandung borak) dari setiap unit perlakuan dan diyatakan dalam satuan presentase. Metode kedua dengan pengukuran absorbansi yaitu dengan memasukkan $2 \mathrm{ml}$ hasil reaksi antara ekstrak bakso dengan reagen Curcumax (sebagai standar) ke dalam kuvet yang digunakan pada alat spektrofotometer. Selanjutnya penilaian perubahan warna diukur menggunakan spektrofotometer pada panjang gelombang $570 \mathrm{~nm}$ (Yiu et al. 2008 dengan modifikasi). Angka absorbensia yang ditunjukkan spektrofotometer dicatat untuk dianalisis. Semua data dianalisis menggunakan Analysis of Varian (ANOVA) dan uji dilanjutkan dengan least significant difference (LSD) apabila ada perbedaan antar kelompok perlakuan.

\section{Hasil dan Pembahasan}

\section{Pengujian Bakso yang Mengandung Boraks dengan Reagen Curcumax}

Asam borak, menurut (Murray, 2005) masih diperbolehkan dikonsumsi manusia dengan standar Acceptable Daily Intake (ADI) sebesar $0,88 \mathrm{mg} /$ kg BB per hari. Penentuan tersebut berdasarkan no observable adverse effect level (NAOEL) pada anjing, namun dosis tersebut tidak menimbulkan risiko pada manusia. Kandungan borak di dalam makanan di Indonesia belum diatur meskipun demikian perlu dihindari konsumsi zat tersebut terlebih tidak diketahui kadar di dalam makanan.

Pemeriksaan menggunakan reagen Curcumax sejalan dengan pendapat Mizura et al. (1991) karena senyawa kunyit (curcumin) merupakan senyawa yang spesifik untuk menguji asam borak di dalam bahan pangan dibandingkan dengan senyawa carminic. Curcumax adalah reagen yang mengandung kurkumin (kunyit). Pengamatan hasil uji dengan menggunakan indra penglihatan memperlihatkan bahwa bakso yang mengandung boraks ditandai dengan perubahan warna ekstrak bakso menjadi oranye, sedangkan ekstrak bakso yang tidak mengandung boraks berwarna kuning (Gambar 1).

Kandungan kurkumin dalam reagen Curcumax yang merupakan indikator untuk $\mathrm{Na}_{2} \mathrm{~B}_{4} \mathrm{O}_{7}$ atau $\mathrm{H}_{3} \mathrm{BO}_{3}$ yang memberikan warna merah oranye atau mendekati merah bata tergantung dari jumlah konsentrasi asam boraks dalam bakso. Ekstrak bakso yang tidak mengandung boraks menunjukkan hasil negatif ditandai dengan ekstrak yang tetap berwarna kuning (AOAC, 1990).

Asam klorida merupakan senyawa kimia yang digunakan untuk menguraikan senyawa organik. Asam klorida pada uji boraks dalam bakso ini berfungsi untuk memisahkan senyawa boraks dan bahan-bahan organik di dalam ekstrak daging. Saat boraks terpisah dengan ekstrak daging, boraks akan segera teridentifikasi oleh kombinasi PVA dan kurkumin. Reaksi yang terjadi antara boraks dalam bakso dengan $\mathrm{HCl}$ dalam reagen Curcumax adalah :

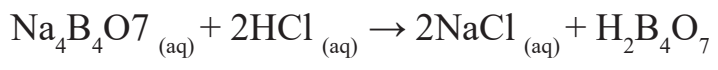
(aq) (Sherman, 1959)

$$
\text { Polimer polyvinyl alcohol (PVA) akan bereaksi }
$$
dengan boraks membentuk masssa liat karena terjadi 


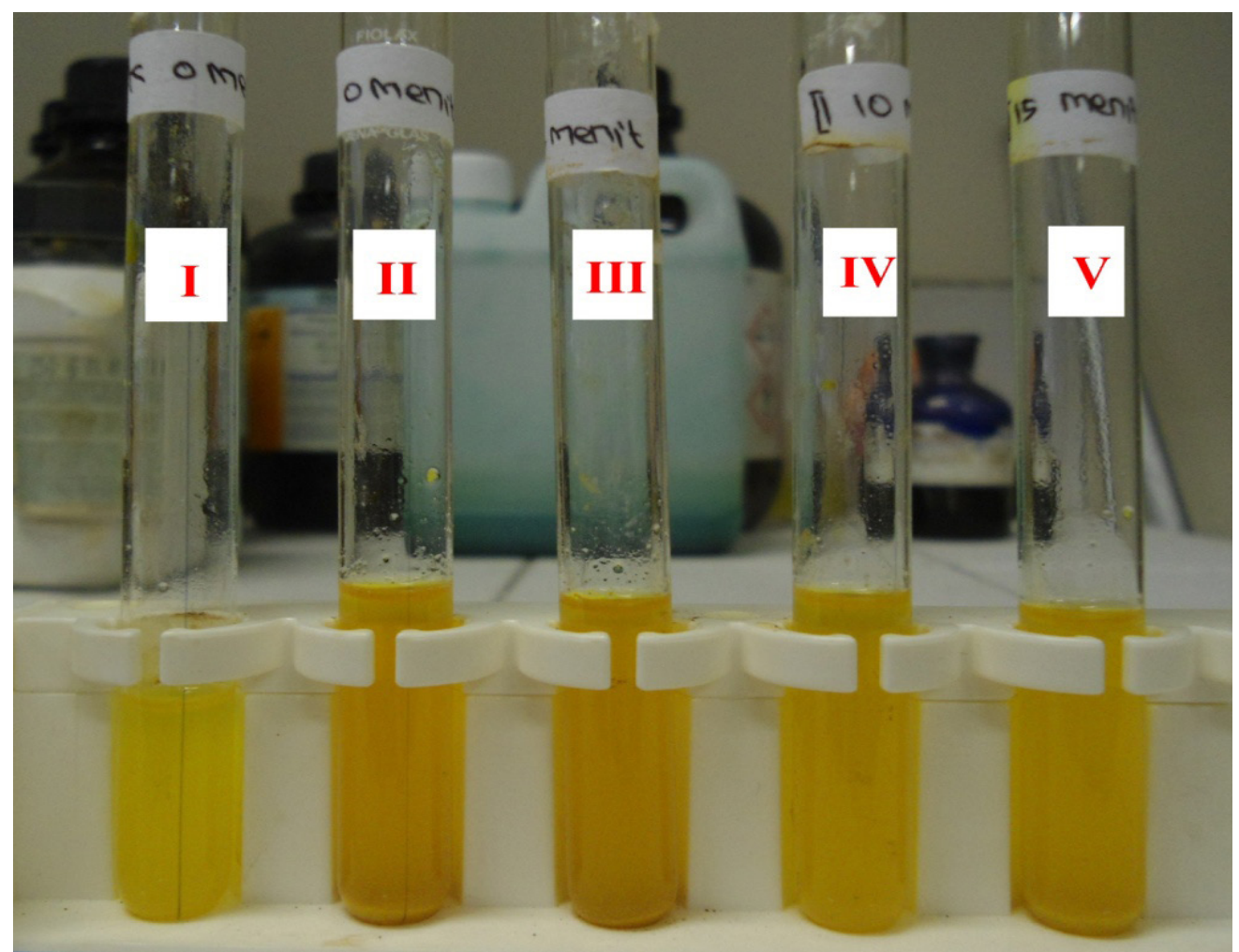

Gambar 1. Perubahan warna ekstrak bakso, kontrol 0 menit (No I) kuning. Warna ekstrak bakso boraks yang mengalami perebusan kembali 0, 5, 10 dan 15 menit (No II, III, IV, V) berubah warna menjadi oranye.

crosslinked polimer. Polyvinyl alcohol juga dapat mencegah kerusakan kunyit (kurkumin) oleh $\mathrm{HCl}$. Perubahan warna dijelaskan oleh Grynkiewicz dan Slifiski (2012) seperti reaksi berikut:

$$
\mathrm{H}_{2} \mathrm{~B}_{4} \mathrm{O}_{7}+\text { curcumin } \rightarrow \text { rosocyanine (warna }
$$
merah oranye).

Rosocyanine dapat terbentuk ketika terjadi reaksi antara kurkumin dengan boraks sehingga menyebabkan warna merah oranye hingga merah pada produk pangan yang mengandung boraks (Grynkiewicz and Slifiski, 2012).

Hasil pengujian reagen Curcumax terhadap ekstrak bakso yang diberi boraks konsentrasi 0,5\% menunjukkan hasil positif dari semua sampel (60 bakaso). Tabel 1 memperlihatkan hasil uji analisis berdasarkan pengelihatan, prosentase bakso kontrol (tanpa boraks) berbeda nyata $(\mathrm{P}<0,05)$ dengan bakso yang mengandung boraks (ANOVA). Pengamatan diantara kelompok bakso boraks yang direbus juga ditemukan adanya perbedaan yang nyata $(\mathrm{P}<0,05)$.

Tabel 1. Presentase perubahan warna ekstrak bakso boraks dan non boraks dengan perlakuan perebusan yang diuji dengan reagen Curcumax

\begin{tabular}{|c|c|c|c|c|}
\hline \multirow{2}{*}{$\begin{array}{l}\text { Kelompok } \\
\text { perlakuan }\end{array}$} & \multicolumn{4}{|c|}{$\begin{array}{l}\text { Presentase bakso setiap perlakuan } \\
\text { (15 sampel) yang berubah warna } \\
(\%) \text { berdasarkan waktu perebusan }\end{array}$} \\
\hline & $\begin{array}{c}\text { Menit } \\
0\end{array}$ & $\begin{array}{c}\text { Menit } \\
5\end{array}$ & $\begin{array}{c}\text { Menit } \\
10\end{array}$ & $\begin{array}{c}\text { Menit } \\
15\end{array}$ \\
\hline Bakso kontrol & $0^{\mathrm{a}}$ & $0^{\mathrm{a}}$ & $0^{\mathrm{a}}$ & $0^{\mathrm{a}}$ \\
\hline $\begin{array}{l}\text { Bakso boraks } \\
0,5 \%\end{array}$ & $100^{\mathrm{a}, 1,3}$ & $93^{\mathrm{a}, 2,3}$ & $47^{\mathrm{a}, 1,2,3}$ & $73^{\mathrm{a}, 3}$ \\
\hline
\end{tabular}

Keterangan: Penandaan huruf sama di dalam kolom atau angka yang sama di dalam baris pada Tabel 1 menunjukkan adanya perbedaan signifikan $(\mathrm{P}<0,05)$.

Analisis lanjut dengan LSD menunjukkan bahwa efefk waktu perebusan kembali bakso boraks pada menit ke 0 (sebelum direbus kembali) berbeda nyata dengan bakso boraks yang direbus lagi selama 
10 menit. Perbedaan nyata $(\mathrm{P}<0,05)$ juga terjadi antara bakso boraks yang direbus selama 5 menit dengan bakso boraks yang direbus selama 10 menit. Namun tidak ada perbedaan nyata pada bakso boraks yang direbus selama 15 menit dengan lama perebusan bakso kontrol maupun terhadap 3 perlakuan perebusan sebelumnya $(0,5$, dan 10 menit).

Uji dengan spektrofotometer dalam penelitian ini menggunakan panjang gelombang $570 \mathrm{~nm}$. Analisis ANOVA dari data hasil pengukuran absorbansi pada Tabel 2 menunjukkan adanya perbedaan nyata $(\mathrm{P}<0,05)$ antara bakso kontrol dengan bakso yang mengandung boraks. Analisis berdasarkan waktu perebusan bakso yaitu 0 menit, 5 menit, 10 menit dan 15 menit memperlihatkan tidak ada perbedaan $(\mathrm{P}>0.05)$ pada kelompok bakso kontrol maupun kelompok bakso boraks.

Tabel 2. Hasil pengukuran absorbansi terhadap panjang gelombang menggunakan spektrofotometer

\begin{tabular}{|c|c|c|c|c|}
\hline \multirow[t]{2}{*}{$\begin{array}{l}\text { Perlakuan } \\
\text { perlakuan }\end{array}$} & \multicolumn{4}{|c|}{$\begin{array}{l}\text { Rerata nilai absorbensia ekstrak } \\
\text { setiap perlakuan berdasarkan } \\
\text { waktu perebusan }(\AA)\end{array}$} \\
\hline & $\begin{array}{l}\text { Menit } \\
0\end{array}$ & $\begin{array}{l}\text { Menit } \\
5\end{array}$ & $\begin{array}{l}\text { Menit } \\
10\end{array}$ & $\begin{array}{l}\text { Menit } \\
15\end{array}$ \\
\hline Bakso kontrol & $0,45^{\mathrm{b}}$ & $0,47^{\mathrm{b}}$ & $0,36^{\mathrm{b}}$ & $0,44^{\mathrm{b}}$ \\
\hline Bakso boraks & $0,83^{\mathrm{b}}$ & $0,71^{\mathrm{b}}$ & $0,67^{\mathrm{b}}$ & $0,58^{\mathrm{b}}$ \\
\hline
\end{tabular}

Keterangan: Penandaan huruf sama di dalam kolom menunjukkan adanya perbedaan signifikan $(\mathrm{P}<0,05)$.

Data hasil pengujian menggunakan panjang gelombang pada waktu rebus kelompok kontrol relatif stabil dengan rerata $0,43 \AA$. Nilai absorbansi berdasarkan lamanya waktu perebusan pada kelompok bakso yang mengandung boraks mengalami penurunan. Bakso yang belum direbus ulang mempunyai rerata nilai absorbansi sebesar 0,83 $\AA$, menurun menjadi $0,71 \AA$ pada 5 menit perebusan dan berturut-turut menjadi $0,67 \AA$ dan $0,58 \AA$ pada 10 dan 15 menit perebusan. Penurunan absorbansi ini terjadi karena spektrum warna yang ditangkap oleh spektrofotometer semakin kecil dan memiliki sifat meneruskan cahaya atau lebih transparan, yaitu dari warna oranye ke kuning. Warna oranye akan menghasilkan absorbansi yang lebih tinggi dari warna kuning. Ekstrak bakso yang mengandung boraks akan berwarna oranye dan warna akan menjadi lebih muda jika kandungan boraksnya berkurang. Berdasarkan hasil pengukuran absorbansi terhadap panjang gelombang tersebut dapat disimpulkan bahwa perebusan kembalipada bakso yang mengandung boraks dapat menyebabkan penurunan kadar boraks di dalam bakso yang digambarkan dengan semakin menurunnya angka absorbensia seiring lamanya perebusan.

Hasil pengukuran menggunakan spektrofotometer terlihat kemampuan deteksi yang lebih tinggi dibandingkan indra penglihatan manusia dalam menangkap spektrum warna secara akurat. Hal ini terlihat dengan perbedaan kecenderungan antara hasil indera penglihatan dengan spektormeter terutama pada menit 10 ke 15 . Pada penglihatan terlihat naik sementara pada hasil spektrofotmeter konsisten turun. Pengujian dengan spektrofotometer memberikan parameter yang menunjukkan kemampuan reagen Curcumax bereaksi dengan boraks dalam masingmasing bakso. Hal ini sejalan dengan penlitian Yiu et al. (2008) yang memperlihatkan bahaw efek pemanasan akan menurunkan kadar borak di dalam makanan. Pemanasan/perebusan bakso yang mengandung boraks dapat mengurangi kandungan boraks di dalam bakso. Hal ini disebabkan karena boraks memiliki sifat mudah menguap dengan pemanasan dan kehilangan satu molekulnya pada suhu $100^{\circ} \mathrm{C}$ yang secara perlahan berubah menjadi asam metaborat $\left(\mathrm{HBO}_{3}\right)$. Hilangnya satu molekul 
menyebabkan ikatan boraks dalam bakso menjadi lemah (Keenan et al., 1992).

Modifikasi reagen curcumin yang dilakuan Arifin et al. (2008) yaitu Curcumax merupakan langakh untuk memudahkan pengujian di lapangan. Reagen Curcumax merupakan penyempurnaan dari alat deteksi boraks yang telah sering digunakan sebelumnya, yaitu kertas kunyit. Reagen Curcumax dan kertas kunyit mempunyai prinsip yang sama, yaitu di dalam rimpang kunyit terdapat kandungan minyak atsiri kurkumin yang merupakan indikator bagi natrium tetraboraks atau asam boraks yang memberikan warna merah oranye dan diubah menjadi hijau gelap oleh penambahan ammonia, tetapi menjadi merah oranye bila ditambahkan asam Grynkiewicz and Slifiski (2012).

Reagen Curcumax merupakan deteksi boraks yang praktis dan pengujiannya dapat dilakukan di luar laboratorium karena mengurangi risiko operator terkena bahan kimia yang berbahaya $(\mathrm{HCl}$ pekat). Berbeda dengan kertas kunyit yang perlu penambahan asam klorida pekat setelah ekstraksi bakso. Asam klorida pekat merupakan salah satu zat kimia berbahaya karena sifatnya yang mudah menguap sehingga penggunaan harus dilakukan di ruang basa. Asam klorida pekat mudah terbakar dan menyebabkan iritasi pada kulit (Arifin et al, 2012).

Interpretasi pengujian reagen Curcumax lebih cepat dibandingkan dengan kertas kunyit. Kertas kunyit membutuhkan waktu kurang lebih 2 menit untuk melihat hasil interpretasi, sedangkan reagen Curcumax hanya membutuhkan waktu 5 detik untuk melihat hasil interpretasi (Arifin et al., 2012). Penelitian ini semakin menguatkan bahwa bahwa reagen Curcumax merupakan alat uji yang terukur berdasarkan parameter (kuantitatif) absorbensi warna.

\section{Kesimpulan}

Pemanasan menurunkan keberadaan boraks dalam bakso. Pengamatan dengan spektrofotometer terhadap perubahan warna reagen Curcumax dalam ekstrak bakso yang mengandung boraks lebih tepat dibandingkan uji kualitatif dengan penglihatan. Reagen curcumax mampu mendeteksi borak dalam bakso yang direbus hingga 15 menit.

\section{Daftar Pustaka}

Arifin, M., Wijaya, A.E., Kusumawardani, A.S., Lutfatin, R.I., Astuti, E.D. 2012. Laporan Akhir PKM-P Curcumax Reagen Praktis Penguji Kandungan Boraks pada Bakso. Universitas Gadjah Mada. Yogyakarta.

AOAC (Association of Official Analytical Chemist). 1990. Official Methods of Analysis. Association of Official Analytical Chemist, USA. 2: 1145, 1146.

Dufour, L., Sander, J.E., Wyatt, R.D.,Rowland, G.N., Page, R.K. 1992. Experimental Exposure Of Broiler Chicken To Boric Acid To Assess Clinical Signs And Lesions Of Toxicosis. Avian Dis. 36 (4):1007-1011.

Grynkliewicz, G., Slifiski, P. 2012. Curcumin and Curcuminoid in Quest for Medicinal Status. ACTA ABP. $59: 205$.

Keenan, C.W., Kleinfelter, D.C., Wood, J.H. 1992. Ilmu Kimia untuk Universitas edisi keenam Jilid 2. Penerbit Erlangga. Jakarta 126-143.

Mizura, S.S, Tee, E.S., Ooi, H.E. 1991. Determination of Boric Acid in Foods: Comparative Study of Three Meethods. J. Sci. Food Agric. 55:261-268

Muray, F. 2005. Risk Assessment of Mattresse ith Borate-Treated Cotton Batting Before and After the Rollest Test. http://www.jonesfiber. com/borontoicity-thefact.pdf. Diakses 2 Desember 2012.

Sander, J.E., Dufour, L., Wyatt, R.D., Bush, P.B., Page, R.K. 1991. Acute Toxicity Of Boric Acid 
And Boron Tissue Residues After Chronic Exposure In Broiler Chicken. Avian Dis. 35 (4):745-749

See, A.S., Salleh, A.B, Bakar, F.A., Yuso, NA., Abdulamir, A.S., Heng, L.Y. 2010. Risk and Health Effect of Boric Acid. Am. J. Applied Sci. 7(5):620-627

Sherman, H.C. 1959. Chemistry of Food and Nutrition. The Macmillan Company. New York. 247.
Sugiyatmi. S. 2006. Analisis Faktor-Faktor Risiko Pencemaran Bahan Toksik Boraks Dan Pewarna Pada Makanan Jajanan Tradisional Yang Dijual Di Pasar-Pasar Kota Semarang Tahun 2006. Tesis. Universitas Diponegoro. Semarang. 7.

Yiu, P.H., See, J., Rajan, A, Bong, A.F.J. 2008. Boric Acid in Fresh Noodles and Fish Ball. Am. J. Agril. \& Biol.Sci. 3(2):476-481 